\title{
TNFRSF17 wt Allele
}

National Cancer Institute

\section{Source}

National Cancer Institute. TNFRSF17 wt Allele. NCI Thesaurus. Code C97847.

Human TNFRSF17 wild-type allele is located in the vicinity of 16p13.1 and is approximately $3 \mathrm{~kb}$ in length. This allele, which encodes tumor necrosis factor receptor superfamily member 17 protein, plays a role in cytokine binding and signaling pathways. A chromosomal translocation $\mathrm{t}(4 ; 16)(q 26 ; p 13)$ of this gene and the IL2 gene is associated with T-cell acute lymphoblastic leukemia. 